\title{
SOSIALISASI PENGGUNAAN SOFTWARE GEOGEBRA PADA SISWA MADRASAH ALIYAH MUQIMUSSUNAH PALEMBANG
}

\author{
Ensiwi Munarsih1) \\ 1)Program Studi Farmasi Sekolah Tinggi Ilmu Farmasi Bhakti Pertiwi Palembang \\ Jl. Ariodillah III No. 22 A Palembang 30128 \\ Email : ensiwi.munarsih@gmail.com ${ }^{1)}$
}

\begin{abstract}
ABSTRAK
Perkembangan teknologi informasi dan komunikasi saat ini telah menjadi pusat perhatian di berbagai bidang kehidupan manusia, salah satunya adalah bidang pendidikan. Teknologi informasi dan komunikasi dalam bidang pendidikan mempunyai peranan penting pada proses pembelajaran, yaitu mentransfer ilmu pengetahuan diantaranya pada proses pembelajaran matematika. Penggunaan software Geogebra merupakan salah satu pemanfaatan teknologi informasi pada bidang pendidikan. Salah satu upaya pengenalan software Geogebra dengan melaksanakan sosialisasi penggunaan software Geogebra tersebut pada siswa Madrasah Aliyah Muqimussunah Palembang. Proses kegiatan dilaksanakan selama 1 hari. Tujuan kegiatan ini adalah memberikan penjelasan tentang manfaat penggunaan Software Geogebra sebagai salah satu media pembelajaran yang cukup menarik untuk menyelesaikan permasalahan -permasalahan dalam bidang geometri, aljabar dan kalkulus.
\end{abstract}

Kata kunci : media pembelajaran, matematika, software Geogebra

\section{PENDAHULUAN}

\subsection{Latar Belakang}

Perkembangan teknologi informasi dan komunikasi saat ini telah menjadi pusat perhatian di berbagai bidang kehidupan manusia, salah satunya adalah bidang pendidikan( Muhson , 2010). Teknologi informasi dan komunikasi dalam bidang pendidikan mempunyai peranan penting pada proses pembelajaran, yaitu mentransfer ilmu pengetahuan. Salah satunya pada proses pembelajaran matematika ( Manoy, 2014) Kehadiran perangkat komputer sebagai sarana dalam proses pembelajaran matematika telah disambut dengan baik. Sebagai contoh penggunaan komputer dalam pembelajaran matematika adalah penggunaan software Geogebra. Penggabungan antara perintah-perintah geometri, aljabar dan kalkulus dapat menjadikan software Geogebra sebagai media pilihan dalam menyampaikan konsep geometri, aljabar maupun kalkulus di sekolah. Konsep yang bersifat abstrak membuat siswa mempunyai beban kognitif yang lebih berat.

Dengan berbagai keunggulan yang dimilikinya, saat ini software Geogebra banyak dimanfaatkan sebagai alat bantu untuk mengkonstruksi, mendemonstrasikan atau memvisualisasikan konsepkonsep abstrak yang ada pada matematika khususnya pada bidang geometri. Software Geogebra sangat mudah diperoleh karena dapat diunduh secara gratis. Di samping itu, software Geogebra juga sangat mudah dioperasikan karena menggunakan sintaks atau perintah yang sangat sederhana. Melihat kemudahan dalam memperoleh maupun dalam pengoperasiannya, sudah selayaknya siswa-siswa sekolah mengengah tingkat pertama mempertimbangkan untuk menggunakan software Geogebra dalam mengajarkan materi-materi geometri yang memang dirasakan abstrak dan sulit bagi sebagian besar siswa di tingkat SMP/MTs. Oleh karena itu, penggunaan software Geogebra diharapkan dapat memotivasi siswa untuk lebih tertarik dan lebih mudah dalam memahami konsep-konsepnya ( Ibrahim dkk, 2001).

Sosialisasi penggunaan software Geogebra diharapkan dapat menambah kemampuan dan pengetahuan siswa dalam pemanfaatan media pembelajaran yaitu media komputer. Sosialisasi ini telah dilaksanakan pada siswa Madrasah Aliyah Muqimussunnah Palembang pada 3 Maret 2018. Melalui kegiatan ini diharapkan pengetahuan dan minat siswa dalam pemanfaatan media komputer pada proses pembelajaran semakin meningkat. 


\subsection{Tujuan}

Tujuan yang hendak dicapai dari program ini adalah memberikan sosialisasi pada siswa-siswa Madrasah Aliyah Muqimussunah Palembang tentang pemanfaatan Software Geogebra sebagai salah satu media pembelajaran yang cukup menarik untuk menyelesaikan permasalahan -permasalahan dalam bidang geometri, aljabar dan kalkulus.

\subsection{Manfaat}

Kegiatan yang dilaksanakan ini nantinya diharapkan dapat menambah pengetahuan dan minat siswa dalam menggunakan dan memanfaatkan software Geogebra pada pembelajaran matematika dalam upaya untuk mempermudah siswa dalam memahami dan menyelesaikan permasalahanpermasalahn dalam bidang geometri, aljabar dan kalkulus.

\subsection{Bentuk Kegiatan}

Beberapa kegiatan yang dilakukan pada kegiatan ini yaitu pemaparan materi dan contoh Software Geogebra serta diakhiri dengan proses tanya jawab.

\section{METODE PELAKSANAAN PENGABDIAN}

\subsection{Persiapan Pelaksanaan Kegiatan}

Sebelum melaksanakan kegiatan Pengabdian kepada Masyarakat di Madrasah Aliyah Muqimussunnah Palembang, ada beberapa tahapan persiapan yang harus dilakukan antara lain :

1) Melakukan kunjungan awal ke tempat yang akan dijadikan lokasi kegiatan pengabdian kepada masyarakat

2) Menyusun proposal kegiatan

3) Pengajuan permohonan izin dan proposal kegiatan pada Ketua Sekolah Tinggi Ilmu Farmasi Bhakti Pertiwi dan Ketua LPPM STIFI Bhakti Pertiwi tentang kegiatan pengabdian pada masyarakat yang akan dilakukan.

4) Kepala STIFI Bhakti Pertiwi dan Ketua LPPM STIFI Bhakti Pertiwi menyetujui kegiatan tersebut dengan membuat surat izin pelaksanaan kegiatan pengabdian pada masyarakat.

5) Mengajukan proposal pada Kepala Sekolah Madrasah Aliyah Muqimussunnah Palembang.

6) Persiapan materi yang disampaikan yaitu materi tentang sosialisasi software Geogebra

7) Persiapan perlengkapan untuk kegiatan Pengabdian Kepada Masyarakat

8) Pelaksanaan Kegiatan.

9) Pembuatan Laporan Kegiatan.

\subsection{Peserta}

Peserta sosialisasi kegiatan pengabdian kepada masyarakat ini merupakan siswa Madrasah Aliyah Muqimussunnah Palembang kelas VII.

\subsection{Waktu Kegiatan dan materi dalam kegiatan}

Kegiatan pelatihan dilaksanakan pada hari Selasa, 3 Maret 2018 pukul 09.00 sampai 11.30 Pelaksanaan kegiatan dilakukan dalam waktu 1 hari. Adapun jadwal pelaksanaan seperti pada Tabel.1 berikut :

Tabel 1. Jadwal Pelaksanaan Kegiatan Pengabdian Kepada Masyarakat

\begin{tabular}{|l|l|l|}
\hline Pukul & Materi & Nara Sumber \\
\hline $09.00-09.15$ & Pembukaan & $\begin{array}{l}\text { Guru Madrasah Aliyah } \\
\text { Muqimussunnah Palembang }\end{array}$ \\
\hline $09.15-11.15$ & Sosialisasi dan Diskusi & Ensiwi Munarsih, M.Sc \\
\hline $11.15-11.30$ & Penutup & $\begin{array}{l}\text { Guru Madrasah Aliyah } \\
\text { Muqimussunnah Palembang }\end{array}$ \\
\hline
\end{tabular}




\section{HASIL DAN PEMBAHASAN}

Pada awal kegiatan diberikan beberapa permasalahan pada pelajaran geometri yang telah disesuaikan dengan pelajaran pada kelas mereka. Selanjutnya siswa diajak menjawab permasalahan tersebut dengan menyelesaikan dengan metode yang telah diajarkan oleh guru mereka sebelumnya. Setelah selesai mengerjakan soal tersebut selanjutnya dibagikan materi sosialisasi penggunaan software Geogebra. Siswa diberi materi petunjuk penggunaan software Geogebra dan petujuk penyelesaian masalah menggunakan software Geogebra tersebut. Pada tahap akhir siswa diajak berdiskusi mengenai software Geogebra tersebut.

Berdasarkan hasil evaluasi terhadap pelaksanaan kegiatan pelatihan yang dilaksanakan diperoleh hasil bahwa seluruh peserta terlihat sangat antusias dalam mengikuti sosialisasi tersebut. Hal ini bisa terlihat dari kehadiran peserta mulai dari awal kegiatan sampai akhir kegiatan. Selain itu mereka juga aktif pada proses diskusi. Proses sosialisasi pengunaan software Geogebra ini mampu membuka pemikiran siswa tentang pemanfaatan komputer sebagai media pembelajaran dan menumbuhkan minat siswa untuk menjadikan matematika sebagai pelajaran yang menyenangkan bukan yang membosankan.

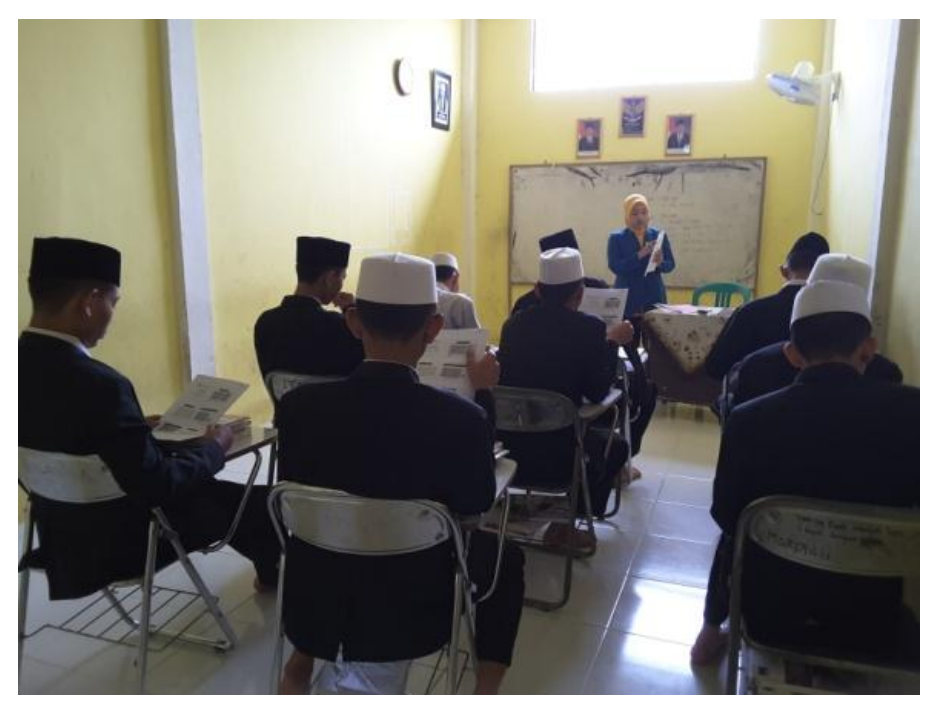

Gambar 1. Pelaksanaan Kegiatan Sosialisasi

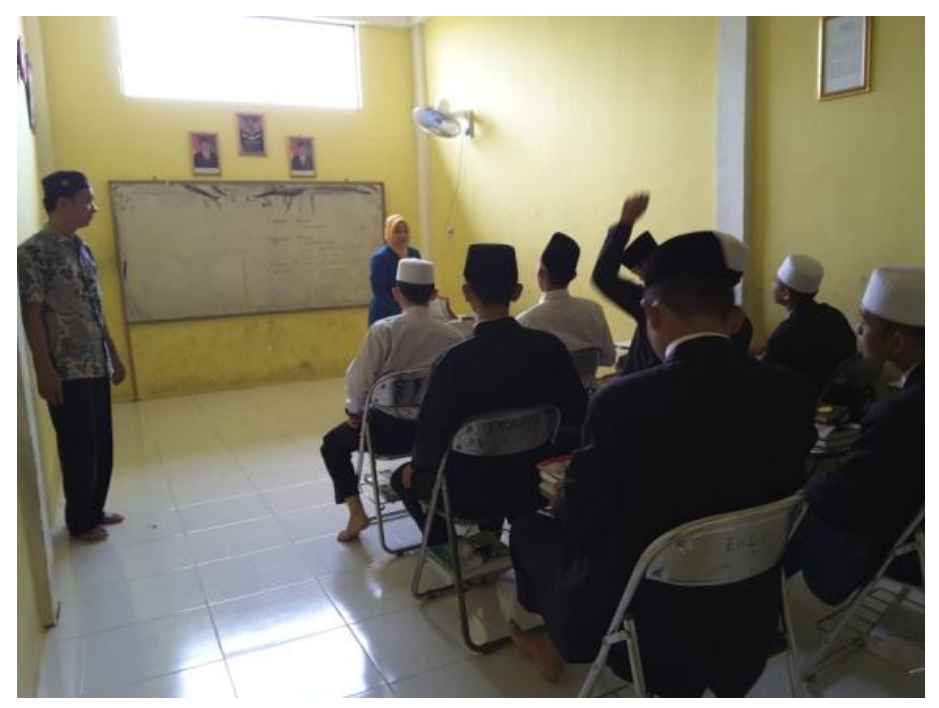

Gambar 2. Pelaksanaan Diskusi 


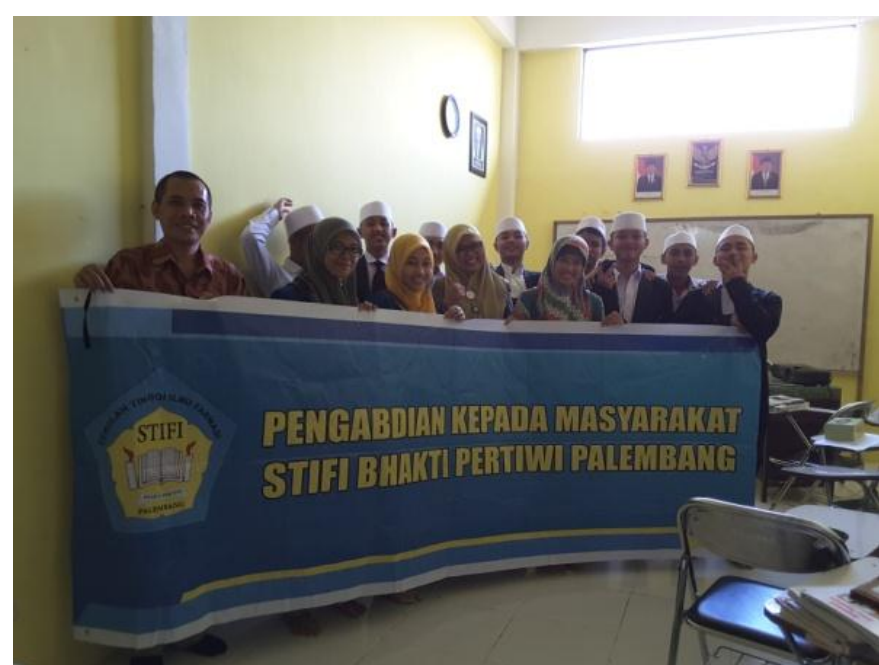

Gambar 3. Foto bersama guru dan siswa MA Muqimussunah

\section{KESIMPULAN}

Laporan kegiatan Pengabdian kepada Masyarakat dapat disimpulkan sebagai berikut

1) Kegiatan terlaksana dengan baik sesuai dengan jadwal yang telah ditetapkan.

2) Kegiatan ini mendapat sambutan yang baik dari siswa MA Muqimussunah Palembang

3) Kegiatan ini menambah pengetahuan para siswa dalam pemanfaatan software Geogebra dan menambah minat mereka terhadap pelajaran matematika khususnya materi geometri.

\section{UCAPAN TERIMA KASIH}

Segala puji dan syukur kami panjatkan kehadirat Alah SWT karena berkat rahmah-Nya, rangkaian kegiatan pengabdian kepada masyarakat ini dapat terselesaikan dengan baik dan sesuai dengan rencana. Pengabdian kepada masyarakat merupakan bagian dari Tri Dharma Perguruan Tinggi bagi setiap dosen. Ucapan terima kasih disampaikan kepada semua pihak yang telah membantu, baik guru maupun siswa MA Muqimussunah Palembang. Terima kasih atas partisipasi yang baik dan penyambutan yang ramah atas kegiatan pengabdian kepada masyarakat ini. Semoga soaialisasi ini member manfaat yang baik terutama bagi siswa MA Muqimussunah Palembang. Laporan akhir kegiatan pengabdian kepada masyarakat ini disusun sebagai rangkuman dari seluruh rangkaian kegiatan pengabdian kepada masyarakat yang telah dilakukan. Dalam penyususnannya laporan ini masih jauh dari kesempurnaan. Saran dan kritik sagat diharapkan demi perbaikan dan penyempurnaan laporan pengabdian kepada Masyarakat ini.

\section{DAFTAR PUSTAKA}

Cooper, Tobias. 2008. Geometry, Functions, and Calculus with GeoGebra. Mans Conference. Jon Arild Jorgensen. Statistics and Geogebra.

Ibrahim, H., Sihkabuden, Suprijanta \& Kustiawan U. 2001. Media Pembelajaran : Bahan sajian program pendidikan akta mengajar. FIP. UM

Manoy, Trineke J. 2014. Modul Alat Peraga Dalam Pembelajaran Matematika, Universitas Terbuka, Jakarta

Muhson, A. 2010. Pengembangan Media Pembelajaran Berbasis Teknologi Informasi, J. Pendidik. Akunt. vol. VIII, no. 2. Indonesia 